\title{
The Scottish low birthweight study: I. Survival, growth, neuromotor and sensory impairment
}

\author{
The Scottish Low Birthweight Study Group*
}

\begin{abstract}
Of all 908 livebirths weighing less than $1750 \mathrm{~g}$ at birth who were born in Scotland in 1984, $896(99 \%)$ were enrolled in a prospective study to document survival and determine the prevalence of neuromotor and sensory impairments and disability.

At the age of 4.5 years, $636(71 \%)$ had survived and $611(96 \%)$ were assessed. Overall $16 \%$ were disabled; 47 had cerebral palsy (52.5/1000 livebirths), seven were blind (7.8/1000 livebirths), and 11 were deaf and using aids (12.3/1000 livebirths). Among those not overtly disabled, the prevalence of poor neuromotor competence was high and related to birth weight.

All growth measures had mean values below the standard population mean indicating a downward shift in the distribution which was related to birth weight. In addition the height distribution was negatively skewed.
\end{abstract}

The improved survival of low birthweight infants documented in routinely collected vital statistics throughout the developed world has to some extent shifted the focus of concern from the risk of death to the quality of life of the children who now survive. ${ }^{1}$ Over the years, reports from individual hospital units of the later outcome of very low birthweight $(<1500 \mathrm{~g})$ children have shown constant rates of disabling conditions that have ranged between $6 \%$ and $8 \%{ }^{2}$ Follow up studies from specialist neonatal intensive care units, however, cannot provide true estimates of the risk of particular outcomes that can be compared with other populations because of the bias resulting from different referral practices. More precise estimates of the risk associated with being of low birth weight can be derived only from the examination of geographically defined populations. ${ }^{3}$

The aim of the current study was to document survival and the prevalence of neuromotor, sensory, and cognitive impairments in the

*Argyll and Clyde Health Board: W Weir, M Camerson. Ayr and Arran Health Board: $M$ Cochrane, $M$ Paterson. Borders Health Board: A Thomson. Dumfries and Galloway Health Board: G Bonn. Fife Health Board: L Fleming. Forth Valley Health Board: E Bengough. Grampian Health Board: $M$ Davidson, S Rodger. Greater Glasgow Health Board: R Frazer, W Povey, J Cunningham. Highlands Health Board: S Kelsey. Lanarkshire Health Board: E Colaco, K MacRae. Lothian Health Board: P Jackson, M Cochrane, A Grant. Orkney and Shetland Health Board: L Hamilton. Tayside Health Board: $R$ Gradwell, N Nolan. Research midwife: V Fletcher. Psychologist: A M McGee. Statisticians: A Leyland, C Pritchard. Coordinator: L Mutch. Advisers: F A Boddy, F Cockburn, D Lloyd, G Mcllwaine, SE Henderson, C Renfrew. geographically defined population of infants weighing less than $1750 \mathrm{~g}$ who were born in Scotland in 1984 and to relate these findings to the perinatal experiences, subsequent morbidity, and social circumstances of the children.

In this paper we present the data on growth and the prevalence of neuromotor and sensory impairments and disability.

\section{Subjects and methods}

Paediatricians providing neonatal care throughout Scotland collaborated in the early stages of the study. Information on all infants weighing less than $1750 \mathrm{~g}$ was provided from every maternity unit in the country and was cross checked with data collected routinely by the Information Statistics Division of the Common Services Agency, which is in turn linked to the Registrar General for Scotland's file on births and deaths. Perinatal data were collected retrospectively by one person (VF) by abstraction from obstetric and neonatal casenotes. Information on the children's status at 2 years was provided by hospital paediatricians, child health clinic doctors, and from health visitor interviews with the parents. ${ }^{4}$

A further assessment of growth and neurodevelopment and cognitive status at 4.5 years was carried out by 20 doctors working in the community child health services of each of the Scottish health boards; these doctors were unaware of the children's neonatal history apart from the fact that they had birth weight less than $1750 \mathrm{~g}$. The doctors were brought together for discussion about the content of the assessment and standardised tests were demonstrated -in two instances by the authors of those tests. A six week pilot period was allowed followed by sessions to test and correct interobserver variation.

This paper is the first of a series and documents the prevalence of clinical outcomes in this population of children.

\section{THE CONTENT OF THE ASSESSMENT}

Height, weight, and head circumference were measured using equipment available in the clinics in which the children were seen and the results standardised for age and sex using reference charts. $^{5-7}$ Where children were assessed in the home, only height and head circumference were measured. A neurological assessment was carried out along the lines suggested by Amiel-Tison and Stewart, ${ }^{8}$ and the child was given a brief clinical examination. 
The Henderson revision of the Stott-MoyesHenderson test of motor impairment (TOMI) was administered. ${ }^{9}$ This test was originally designed to identify children whose motor competence fell into the lowest $15 \%$ of the general population. For the purposes of this study, and with the agreement of the author, we used the 10th centile as a measure of impaired performance. The recommended scoring of the test provides an overall score, but for the purposes of understanding more about the specific problems a child might have, agreement was reached with the test author that the items could be considered separately.

Details of the results of routine vision and hearing checks at school entry were requested from health boards.

\section{DEFINITIONS}

Impairment and disability were graded by the following criteria incorporating those set down in the World Health Organisation (WHO) classification of impairments, disabilities, and handicaps ${ }^{10}$ :

Severe disability: those with neuromotor signs who were unable to sit, stand, or walk independently even with aids; who were blind or had acuity levels of less than $6 / 60$ in the better eye; who were deaf or had a loss greater than $55 \mathrm{~dB}$ and were using aids; or who had an overall short form intelligence quotient (IQ) on the British ability scales of less than 50 (see accompanying paper).

Moderate disability: those with neuromotor signs who could sit, stand, and walk with aids, who had a corrected visual acuity of between $6 /$ 36 and $6 / 60$ in both eyes, who had a hearing loss of 40-55 dB in the better ear even if hearing aids had not been prescribed; or who had an IQ in the range 50-69.

Impairment without disability: those who had neuromotor signs only without overt functional loss; those with a visual acuity of $6 / 18-6 / 24$; or a hearing loss less than $40 \mathrm{~dB}$; or who had an IQ between 70 and 84 .

Overall disability was further divided into whether the child had single or multiple problems.

\section{STATISTICAL ANALYSIS}

Examination of the data did not detect any systematic variation between observers in the rate of abnormality detected except where it was explained by one doctor who saw all the study children who attended a special nursery for disabled children.

Analyses in this paper report on comparisons

Table 1 The number of births and deaths of infants weighing less than $1750 \mathrm{~g}$ at birth, in Scotland in 1984: survival rates by birthweight group

\begin{tabular}{llllll}
\hline & \multicolumn{3}{l}{ Birth weight } & & \\
\cline { 2 - 4 } & $<1000 \mathrm{~g}$ & $1000-1499 \mathrm{~g}$ & $1500-1749 \mathrm{~g}$ & Total \\
\hline $\begin{array}{lllll}\text { No of livebirths } \\
\text { No of neonatal deaths }\end{array}$ & 204 & 398 & 294 & 896 \\
$\begin{array}{l}\text { (rate/1000 livebirths) } \\
\text { No of postneonatal deaths }\end{array}$ & $126(618)$ & $71(178)$ & $20(68)$ & $217(242)$ \\
$\begin{array}{l}\text { Deaths 1-2 years } \\
\text { Deaths 2-4 years }\end{array}$ & 4 & 13 & 9 & 1 & 66 \\
$\begin{array}{l}\text { No of survivors at 4.5 years } \\
\text { (rate/1000 livebirths) }\end{array}$ & 0 & 0 & 1 & 1 \\
No assessed at 4.5 years (\%) & $60(29 \cdot 4)$ & $312(78 \cdot 4)$ & $264(89 \cdot 8)$ & $636(710 \cdot 1)$ \\
\hline
\end{tabular}

of the prevalence of the various outcomes in three birthweight groups (below $1000 \mathrm{~g}$, between 1000 and $1499 \mathrm{~g}$, and $1500-1749 \mathrm{~g}$ using $\chi^{2}$ tests, $\chi^{2}$ test for trend, and comparison of means using Student's $t$ test.

The content of the assessment covers a wide variety of outcomes in the children, some of whom had specific disabilities in one sphere that affected their competence in tests of other skills-for example, a child who is blind is unable to perform a bead threading task. For this reason, and because some children refused some of the tests, the total numbers reported on each test vary. The issue of children who are unable to take part in testing because of disability is addressed in a future paper.

\section{Results}

In Scotland in 1984 there were 1044 registered births of children weighing less than $1750 \mathrm{~g}$ of whom 908 were born alive and eligible for inclusion in the study; $896(98.8 \%)$ were enrolled. Twelve children were not enrolled because they were not reported to the study by medical records officers. They were identified over a year later through routine returns of the Scottish Morbidity Record (SMR2 and 11) data and were therefore not approached for consent.

\section{SURVIVAL RATES}

Of the 896 livebirths, 217 died before 28 days, an overall neonatal mortality rate of 242 per 1000 livebirths, with an appreciable difference between those with birth weights less than and greater than $1000 \mathrm{~g}$ in both singleton and multiple pregnancies (table 1). Female singleton births had higher survival rates than males but this sex difference in survival was not found for multiple births. Infants with birth weights of less than $1000 \mathrm{~g}$ had twice the rate of postneonatal death of the heavier infants. Among neonatal survivors, four times as many children weighing $<1000 \mathrm{~g}$ died before the end of the first year.

Six children died between 1 and 2 years of age and a further child, who had been assessed at 2 years as multiply handicapped, died in an accident at the age of 4 years. In total, $71 \%$ of the children survived until assessment at 4.5 years.

Of the 636 survivors, $611(96 \%)$ were assessed; 12 children had gone abroad, two had been adopted, and six parents refused to have their children assessed. Five children could not be traced after questioning the facilities of the Child Health Register, the National Health Service Register, and the local education authority.

The characteristics of the children and their families are shown in table 2 . Although more boys were born in this birthweight group, their slightly higher mortality rates, particularly among those less than $1000 \mathrm{~g}$, resulted in an approximately equal sex ratio among the survivors. Multiple pregnancies were more common in the lightest weight group. There was no differences between the birthweight groups in maternal age at delivery, the social class of the father, or being part of a single parent family at the time the child was assessed. The social class distribution of the study cohort did not differ 
significantly from that of the total Scottish birth population in 1984 when the high proportion of missing or incomplete social class data were excluded. All but five children were white.

Data from the SMR2 $2^{11}$ on births in the period 1980-6 were used to derive birth weight for gestation standards suitable for the study population (A Leyland et al, unpublished data).

Table 2 Characteristics of the children by birthweight group

\begin{tabular}{|c|c|c|c|c|}
\hline & \multicolumn{3}{|c|}{ Birth weight } & \multirow[b]{2}{*}{ Total } \\
\hline & $<1000 \mathrm{~g}$ & $1000-1499 \mathrm{~g}$ & $1500-1749 \mathrm{~g}$ & \\
\hline Sex ratio at birth (M:F) & 0.92 & $1 \cdot 19$ & $1 \cdot 07$ & 1.08 \\
\hline $\begin{array}{l}\text { Sex ratio of survivors }(M: F) \\
\text { Birth number: } \% \text { singleton }\end{array}$ & $0 \cdot 67$ & $1 \cdot 06$ & $1 \cdot 01$ & 0.99 \\
\hline $\begin{array}{l}\text { Birth number: \% singleton } \\
\text { at birth }\end{array}$ & $72 \cdot 1$ & $78 \cdot 4$ & $83 \cdot 0$ & $78 \cdot 5 t$ \\
\hline \multirow{2}{*}{$\begin{array}{l}\text { Mean maternal age at } \\
\text { delivery (years) } \\
\text { Social class of father at } \\
4 \text { years (\%): }\end{array}$} & $25 \cdot 2$ & $25 \cdot 6$ & $25 \cdot 5$ & $25 \cdot 5$ \\
\hline & $18 \cdot 3$ & $14 \cdot 4$ & $19 \cdot 0$ & $16 \cdot 7$ \\
\hline III non-manual & $8 \cdot 3$ & $5 \cdot 7$ & 5.5 & 5.9 \\
\hline III manual & $23 \cdot 3$ & $35 \cdot 6$ & $30 \cdot 4$ & $32 \cdot 2$ \\
\hline IV and V & $20 \cdot 0$ & $19 \cdot 1$ & $18 \cdot 2$ & $18 \cdot 8$ \\
\hline Other + missing & $30 \cdot 0$ & $25 \cdot 2$ & $26 \cdot 9$ & $26 \cdot 4$ \\
\hline Single parent at 4 years $(\%)$ & $15 \cdot 0$ & $11 \cdot 1$ & $13 \cdot 8$ & $12 \cdot 6$ \\
\hline \multicolumn{5}{|l|}{$\begin{array}{l}\text { Small for dates }(\%<10 \text { th } \\
\text { centile): }\end{array}$} \\
\hline $\begin{array}{l}\text { At birth } \\
\text { Survivors }\end{array}$ & $22 \cdot 4$ & $\begin{array}{l}30.4 \\
35.5\end{array}$ & $38 \cdot 1$ & $\begin{array}{l}31.4 \dagger \\
36.5\end{array}$ \\
\hline \multirow{2}{*}{$\begin{array}{l}\text { Mean (SD) age at } \\
\text { assessment (months) }\end{array}$} & & כ2 & & \\
\hline & $55 \cdot 3(2 \cdot 2)$ & $55 \cdot 5(2 \cdot 6)$ & $55.6(2 \cdot 9)$ & $55 \cdot 5(2 \cdot 7)$ \\
\hline
\end{tabular}

"Singleton births only.

$t \chi^{2}$ for trend $=p<0.005$

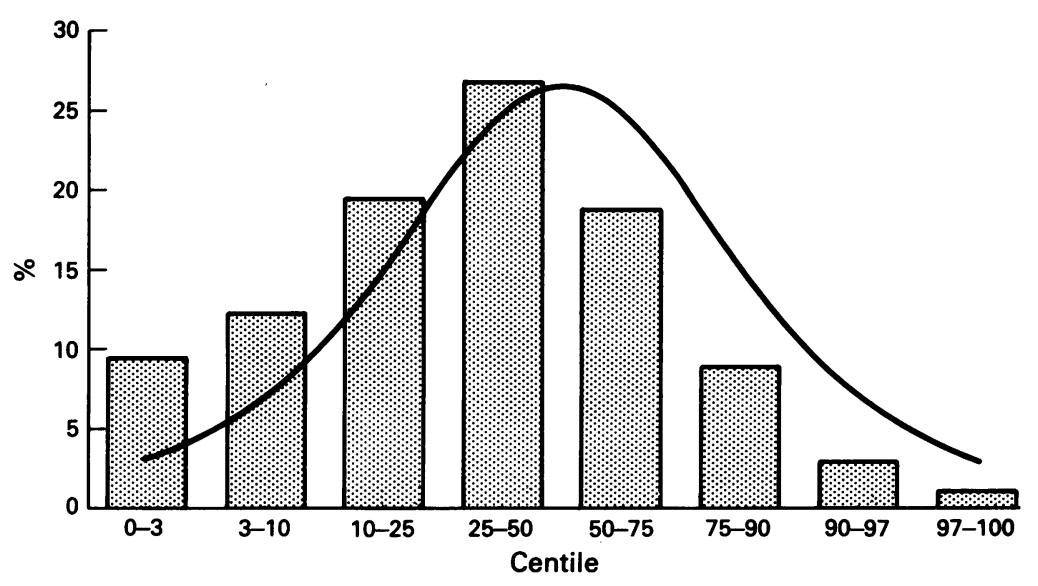

Figure 1 Distribution of height at $4 \cdot 5$ years of all children $<1750 \mathrm{~g}$ at birth, 1984. Based on 601 children; 10 missing cases.

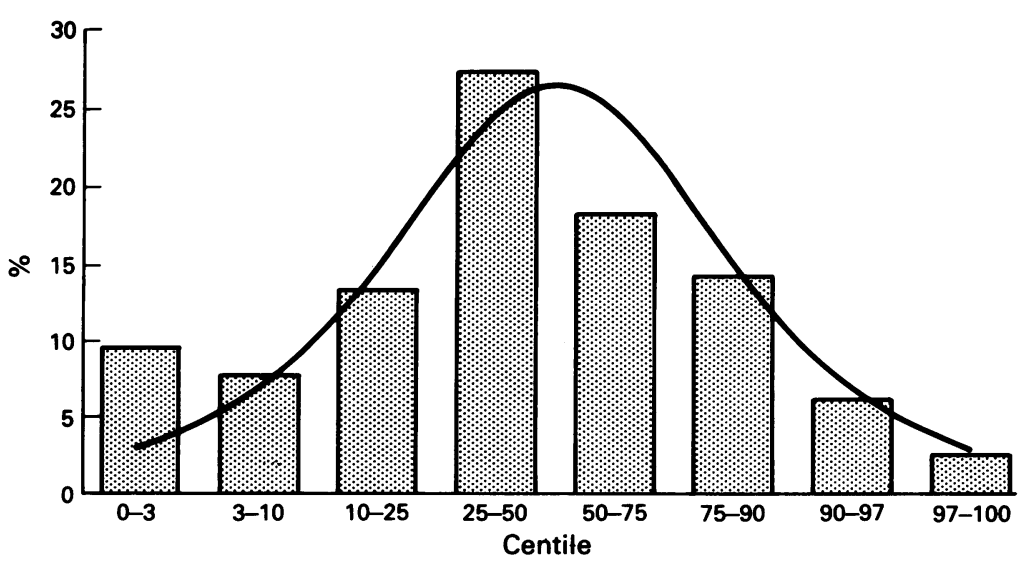

Figure 2 Distribution of head circumference at $4 \cdot 5$ years of all children $<1750 \mathrm{~g}$ at birth, 1984. Based on 603 children; eight missing cases.
Because our study population was defined by birth weight alone, significantly more of the population with birth weights greater than 1000 $\mathrm{g}$ were below the 10th centile of weight for gestation for this population; among survivors, however, a higher proportion of the less than $1000 \mathrm{~g}$ infants were small for dates.

The mean age at assessment was 55.5 months, with no difference between the birthweight groups.

\section{GROWTH}

Figures 1-3 show the distribution of height, head circumference, and weight centiles in the study cohort calculated from standard centile charts using chronological age. ${ }^{56}$ All the growth measures had mean values below the standard population mean, indicating a downward shift in the distribution. This shift was related to the original birth weight. It was only in respect of later weight that children with birth weights less than $1000 \mathrm{~g}$ differed from the rest of the cohort; $90 \%$ of this group had weights less than the 50 th centile at 4.5 years.

In addition, the height distribution was negatively skewed (skewness $-0 \cdot 67$, SE $0 \cdot 13$ ). Boys' height was more affected than girls with the result that there was a sex difference in body mass index (weight/height ${ }^{2}$ ). Figure 4 shows that there was excess of children with body mass index below the 50th centile-that is, they were light for their height.

The heights and weights of children who were originally small for dates did not differ significantly from those of the other study children, but a statistically significantly higher proportion of them had head circumferences less than the 10th centile ( $p<0.005)$.

\section{NEUROMOTOR IMPAIRMENT}

The observed birthweight gradient in the proportion of surviving children who had neuromotor impairment with disability was statistically significant but no gradient was seen in the rate per 1000 livebirths (table 3). Thirty five children $(5 \cdot 7 \%)$ had clinical signs only, most commonly restricted dorsiflexion of the ankles or tight hamstrings which were not sufficiently severe to stop them functioning, albeit clumsily.

\section{SENSORY IMPAIRMENT}

Sensory impairment was commoner in children with birth weights less than $1000 \mathrm{~g}$. Seven children were blind and 70 had squints frequently associated with a more general neuromotor impairment. Twelve children overall had nystagmus denoting a central lesion.

Information on refractive errors was not available for all the children in three health boards, partly because children moved schools. For children who were living in England we were not in a position to obtain this information. Records were available for 478 children of whom $22(3.5 \%)$, in addition to those who were blind, had a visual acuity level of $6 / 18$ or less in both eyes. This finding was related to birth weight, with $9 \%$ of those with birth weights 


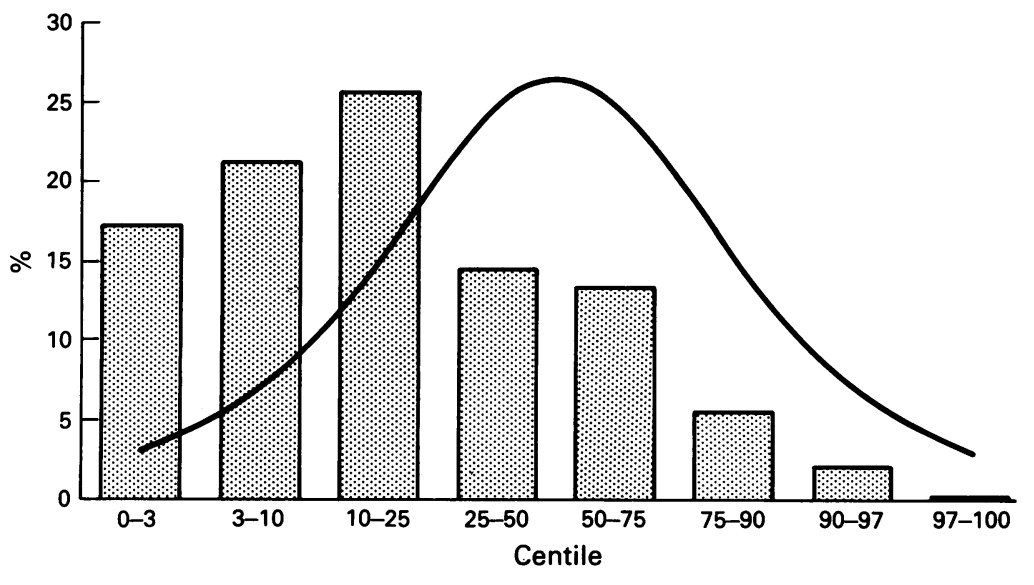

Figure 3 Distribution of weight at 4.5 years of all children $<1750 \mathrm{~g}$ at birth, 1984. Based on 551 children; 60 missing cases.

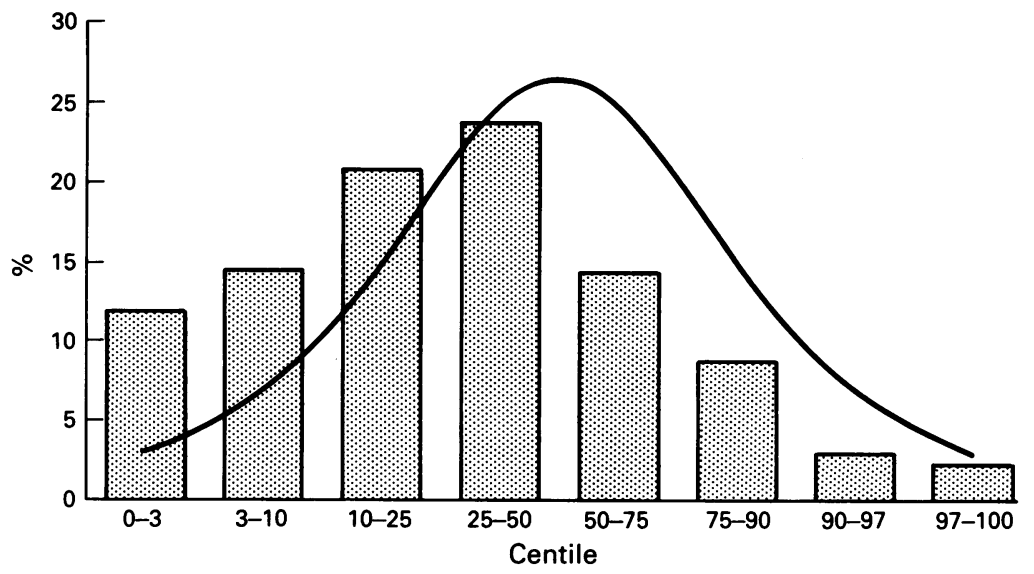

Figure 4 Distribution of body mass index at $4 \cdot 5$ years of all children $<1750 \mathrm{~g}$ at birth, 1984. Based on 551 children; 60 missing cases.

Table 3 The number (\%) of children with neuromotor and sensory impairment by birthweight group

\begin{tabular}{|c|c|c|c|c|}
\hline & \multicolumn{3}{|c|}{ Birth weight } & \multirow[b]{2}{*}{ Total } \\
\hline & $<1000 \mathrm{~g}$ & $1000-1499 \mathrm{~g}$ & $1500-1749 \mathrm{~g}$ & \\
\hline \multirow{3}{*}{$\begin{array}{l}\text { No of children assessed } \\
\text { Neuromotor impairment } \\
\text { Abnormal signs only } \\
\text { Impairment with disability: } \\
\text { Severe } \\
\text { Moderate } \\
\text { Rate of neuromotor disability/ } \\
1000 \text { livebirths } \\
95 \% \text { CI }\end{array}$} & $\begin{array}{l}60 \\
13(21 \cdot 6) \\
5(8 \cdot 3)\end{array}$ & $\begin{aligned} 298 & \\
42 & (14 \cdot 1) \\
16 & (5 \cdot 4)\end{aligned}$ & $\begin{array}{l}253 \\
27(10 \cdot 7) \\
14(5 \cdot 5)\end{array}$ & $\begin{array}{l}611 \\
82(13.4) \dagger \\
35(5 \cdot 7)\end{array}$ \\
\hline & $\begin{array}{l}4(6 \cdot 7) \\
4(6 \cdot 7)\end{array}$ & $\begin{array}{l}10(3 \cdot 4) \\
16(5 \cdot 4)\end{array}$ & $\begin{array}{l}9(3 \cdot 6) \\
4(1 \cdot 6)\end{array}$ & $\begin{array}{l}23(3 \cdot 8) \\
24(3 \cdot 9)\end{array}$ \\
\hline & $\begin{array}{l}39 \cdot 2 \\
17 \cdot 1 \text { to } 75 \cdot 8\end{array}$ & $\begin{array}{l}65 \cdot 3 \\
43 \cdot 1 \text { to } 94 \cdot 3\end{array}$ & $\begin{array}{l}44 \cdot 2 \\
23 \cdot 8 \text { to } 74 \cdot 4\end{array}$ & $\begin{array}{l}52 \cdot 5 \\
37.9 \text { to } 67 \cdot\end{array}$ \\
\hline \multirow{2}{*}{$\begin{array}{l}\text { Visual impairment: } \\
\text { Blind } \\
\text { Squints } \\
\text { Nystagmus } \\
\text { Visual acuity }<6 / 18 \\
\text { Rate of blindness } / 1000 \\
\text { livebirths } \\
95 \% \text { CI }\end{array}$} & $\begin{aligned} 3 & (5 \cdot 0) \\
12 & (20 \cdot 0) \\
5 & (8 \cdot 8) \\
5 & (9 \cdot 4)\end{aligned}$ & $\begin{aligned} & 1(0 \cdot 3) \\
& 35(11 \cdot 8) \\
& 2(0 \cdot 7) \\
& 10(4 \cdot 4)\end{aligned}$ & $\begin{aligned} 3 & (1 \cdot 2) \\
23 & (9 \cdot 2) \\
5 & (2 \cdot 0) \\
7 & (3 \cdot 6)\end{aligned}$ & $\begin{aligned} & (1 \cdot 1) \\
70 & (11 \cdot 6) \\
12 & (2 \cdot 0) \\
22 & (4 \cdot 6)\end{aligned}$ \\
\hline & $\begin{array}{l}14 \cdot 7^{*} \\
3 \cdot 0 \text { to } 42 \cdot 4\end{array}$ & $\begin{array}{l}2.5 \\
0.0 \text { to } 13.9\end{array}$ & $\begin{array}{l}10 \cdot 2 \\
2 \cdot 1 \text { to } 29 \cdot 6\end{array}$ & $\begin{array}{l}7 \cdot 8 \\
3 \cdot 1 \text { to } 16 \cdot\end{array}$ \\
\hline \multirow{2}{*}{$\begin{array}{l}\text { Hearing impairment: } \\
\text { Deaf with aids } \\
\text { Hearing loss }>40 \mathrm{~dB} \\
\text { Rate of deafness } / 1000 \\
\text { livebirths } \\
95 \% \mathrm{CI}\end{array}$} & $\begin{array}{l}2(3 \cdot 0) \\
0\end{array}$ & $\begin{array}{l}4(1.4) \\
2(0.6)\end{array}$ & $\begin{array}{l}5(2 \cdot 0) \\
2(0 \cdot 7)\end{array}$ & $\begin{array}{r}11(1 \cdot 8) \\
4(0 \cdot 6)\end{array}$ \\
\hline & $\begin{array}{l}9 \cdot 8 \\
1.2 \text { to } 34.9\end{array}$ & $\begin{array}{l}10 \cdot 0 \\
2 \cdot 7 \text { to } 25 \cdot 5\end{array}$ & $\begin{array}{l}17 \cdot 1 \\
5 \cdot 6 \text { to } 39 \cdot 4\end{array}$ & $\begin{array}{l}12 \cdot 3 \\
4 \cdot 6 \text { to } 17 \cdot 5\end{array}$ \\
\hline
\end{tabular}

$\mathrm{CI}=$ confidence intervals.

$\chi^{2},{ }^{*} \mathbf{p}<0.01 ; \chi^{2}$ for trend: $\neq \mathrm{p}<0.05, \neq \mathrm{p}<0.025$. below $1000 \mathrm{~g}$ being affected, compared with $4 \%$ of those over $1000 \mathrm{~g}$ at birth.

Eleven children ( $2 \%$ of those for whom results were available) were deaf and using hearing aids and a further four had bilateral losses of $40 \mathrm{~dB}$ or more; infants who had been less than $1000 \mathrm{~g}$ at birth did not have an increased risk of deafness. Information on the results of school entry screening was available for $526(86 \%)$ of the children. In the case of 19 children $(3.6 \%)$, where the 'sweep' test had been reported as abnormal, the results of audiometry were not available.

\section{MOTOR COMPETENCE}

The results of the TOMI for children without a known neuromotor or visual disability are presented in table 4 . On the overall score the children performed significantly less well than the population on whom the test was standardised, even in the absence of neuromotor disability with $40 \%$ of those below $1000 \mathrm{~g}$ being considered impaired compared with $20 \%$ and $16 \%$ in the heavier groups respectively. This trend was, however, statistically significant only in respect of performance of the tasks of bead threading, one leg balance, and jumping the cord. Where there was no trend by birth weight, the extremely low birthweight infants $(<1000 \mathrm{~g})$ performed less well on catching a bean bag and rolling a ball into a goal. Nearly a fifth of all the study children could not jump a cord at knee height but in children who had birth weights less than $1000 \mathrm{~g}, 36 \%$ failed this task, whereas $90 \%$ of the reference population on whom the test was standardised could achieve it.

In tests of fine motor skills the study children were poor at, for example, controlling a pencil to draw between two lines (the bicycle trail task), with nearly a quarter of those over $1000 \mathrm{~g}$ and $30 \%$ of the extremely low birthweight children scoring below the 10th centile for the tests.

\section{DISABILITY STATUS}

Children were classed into four categories: (i) severely disabled with single or multiple systems involved; (ii) moderately disabled with single or multiple systems involved; (iii) impaired but not disabled; and (iv) as having no detectable impairment. These overall categories took neuromotor and sensory status into account, and the level of cognitive impairments described in the accompanying paper. Using the criteria described earlier in the paper, 36 of the whole cohort $(5.9 \%)$, were severely disabled; in those children weighing less than $1000 \mathrm{~g}$, this proportion was $13 \%$, and in the higher birthweight groups, it was $5 \%$ (table 5 ). More than half $(55 \%)$ of the cohort were free of obvious impairment, ranging from 42 to $58 \%$ between the lowest and the highest birthweight groups. Multiple disabilities were twice as common in the $<1000 \mathrm{~g}$ group as in the heavier children.

\section{Discussion}

Longer term follow up of low birthweight children is expensive and is logistically difficult 
Table 4 Motor competence in children with no known neuromotor or visual disability: number (\%) children <10th centile for individual tests by birthweight group

\begin{tabular}{|c|c|c|c|c|}
\hline & \multicolumn{3}{|c|}{ Birth weight } & \multirow[b]{2}{*}{ Total } \\
\hline & $<1000 \mathrm{~g}$ & $1000-1499 \mathrm{~g}$ & $1500-1749 \mathrm{~g}$ & \\
\hline $\begin{array}{l}\text { Rolling ball into goal } \\
\text { Catching beanbag } \\
\text { Threading beads } \\
\text { Posting coins } \\
\text { Bicycle trail } \\
\text { Jumping cord } \\
\text { Walking heels raised } \\
\text { One leg balance } \\
\text { Overall score§ }\end{array}$ & $\begin{array}{l}11(23 \cdot 4)^{*} \\
12(25 \cdot 5)^{*} \\
14(29 \cdot 7) \\
13(28 \cdot 9) \\
15(31 \cdot 9) \\
17(36 \cdot 2) \\
12(25 \cdot 5) \\
16(34 \cdot 0) \\
18(40 \cdot 0)\end{array}$ & $\begin{array}{l}26(10 \cdot 1) \\
30(11 \cdot 6) \\
53(20 \cdot 5) \\
46(18 \cdot 0) \\
54(21 \cdot 0) \\
58(22 \cdot 5) \\
37(14 \cdot 3) \\
50(19 \cdot 5) \\
51(20 \cdot 2)\end{array}$ & $\begin{array}{l}26(10 \cdot 9) \\
29(12 \cdot 2) \\
32(13 \cdot 4) \\
37(15 \cdot 7) \\
52(21 \cdot 8) \\
38(15 \cdot 9) \\
31(13 \cdot 0) \\
40(16 \cdot 8) \\
39(16 \cdot 5)\end{array}$ & $\begin{aligned} & 63(11 \cdot 6) \\
& 71(13 \cdot 1) \\
& 99(18 \cdot 2) \dagger \\
& 96(17 \cdot 9) \\
& 121(22 \cdot 3) \\
& 113(20 \cdot 8) \ddagger \\
& 80(14 \cdot 7) \\
& 106(19 \cdot 6) \dagger \\
& 108(20 \cdot 3) \ddagger\end{aligned}$ \\
\hline
\end{tabular}

Overall score for those who did all tasks.

Table 5 Overall disability rating of children: number (\%) by birthweight group

\begin{tabular}{|c|c|c|c|c|}
\hline & \multicolumn{3}{|l|}{ Birth weight } & \multirow[b]{2}{*}{ Total } \\
\hline & $<1000 \mathrm{~g}$ & $1000-1499 \mathrm{~g}$ & $1500-1749 \mathrm{~g}$ & \\
\hline $\begin{array}{l}\text { No of survivors } \\
\text { Unimpaired at } 4.5 \text { years } \\
\text { Impaired but not disabled } \\
\text { Moderate disability: }\end{array}$ & $\left.\begin{array}{l}60 \\
25(41 \cdot 7) \\
15(25 \cdot 0)\end{array}\right\}^{*}$ & $\begin{array}{l}298 \\
162(54 \cdot 4) \\
90(30 \cdot 2)\end{array}$ & $\begin{array}{l}253 \\
147(58 \cdot 1) \\
69(27 \cdot 3)\end{array}$ & $\left.\begin{array}{l}611 \\
334(54 \cdot 7) \\
174(28 \cdot 5)\end{array}\right\}+$ \\
\hline $\begin{array}{l}\text { Single system } \\
\text { Multiple systems }\end{array}$ & $\begin{aligned} & 10(16 \cdot 7) \\
& 2(3 \cdot 3)\end{aligned}$ & $\begin{array}{l}22(7 \cdot 4) \\
10(3 \cdot 4)\end{array}$ & $\begin{array}{r}18(7 \cdot 1) \\
5(2 \cdot 0)\end{array}$ & $\begin{array}{l}50(8 \cdot 2) \\
17(2 \cdot 8)\end{array}$ \\
\hline $\begin{array}{l}\text { Severe disability: } \\
\text { Single system } \\
\text { Multiple systems }\end{array}$ & $\left.\begin{array}{l}3(5 \cdot 0) \\
5(8 \cdot 3)\end{array}\right\}^{*}$ & $\begin{array}{l}7(2 \cdot 3) \\
7(2 \cdot 3)\end{array}$ & $\begin{array}{l}6(2 \cdot 4) \\
8(3 \cdot 2)\end{array}$ & $\begin{array}{l}16(2 \cdot 6) \\
20(3 \cdot 3)\end{array}$ \\
\hline
\end{tabular}

because of the problem of tracing children but more studies of children who were of low birth weight and who are now reaching or have just reached school age are now being reported. The majority are, however, based on the survivors of neonatal care in a single intensive care setting. ${ }^{12-14}$ Where geographically based studies are available, the population described is usually enrolled over a period of several years, during which time elements of the perinatal care they received may have subtly changed ${ }^{15-17}$; some have reported only at earlier ages. ${ }^{18}$ Sometimes these studies have reported on children covering a wide age range of subjects at the time of assessment with the consequence that the same methods of assessment were not appropriate for the whole study population. ${ }^{15}$

Many studies have reported on the poorer growth of low birthweight infants. ${ }^{19-24}$ In our cohort, the distributions of all measures of growth were shifted downwards with the most marked effect being for weight; a similar pattern was reported by Casey et al. ${ }^{25} \mathrm{~A}$ quarter of the children with heights below the 3rd centile had severe cerebral palsy and this finding was independent of social class and mean parental heights. The head circumference of children with cerebral palsy formed a $U$ shaped distribution with just over $30 \%$ being above the 97 centile. $^{26}$

In all published studies, the prevalence of neuromotor and sensory impairment is related to the original birth weight with the smallest infants having the highest rate of impairment. This finding is borne out by our study. In the report of Kitchen et al (1982) over 13 years of the outcome for infants of less than $1500 \mathrm{~g}$ from Melbourne, the proportion of surviving children with cerebral palsy rose in three time periods, the rates for 1966-70, 1973-4, and 1977-8 being
$2 \cdot 6,4 \cdot 5$, and $11 \cdot 9 \%$ respectively. Survival rates were $37 \%$ in the first two cohorts and $68 \%$ in the third. ${ }^{27}$ In Scotland, survival rates in 1984, six years later, were $62 \%$ for children weighing less than $1500 \mathrm{~g}$ at birth with a cerebral palsy rate of $\mathbf{9 . 8 \%}$ among the survivors. In a more recent report of infants who weighed less than $1000 \mathrm{~g}$, born in the same tertiary centre in Melbourne between $1978-80,{ }^{28} 8 \cdot 3 \%$ (five of 60 survivors) had cerebral palsy compared with $13 \cdot 3 \%$ (eight of 60) in our study.

In these authors' regional study of 1979-80 births under $1000 \mathrm{~g}$, however, the prevalence of cerebral palsy was identical to ours at $13 \cdot 5 \%$. $^{29}$ This highlights the importance of comparing geographically defined and thus similar populations. ${ }^{30}$

Johnson and her colleagues (1987), in a population based cohort study in Newfoundland, ${ }^{31}$ reported similar survival rates for infants $<1500 \mathrm{~g}$ born in $1980-1 ; 10 \%$ of the survivors had significant disability (including cerebral palsy) at 3 years whereas $6 \%$ of our $<1500 \mathrm{~g}$ cohort had severe disability. Some of this difference may result from definitions of disability grades, but also, because our children were older, we were able to include measures of cognitive ability in the overall categorisation of disability.

When a prospective cohort approach has been employed it has been suggested that neurodevelopmental assessments at 1 year are predictive of neuromotor status at four years. ${ }^{32}$ On the other hand, studies of the prevalence of cerebral palsy in populations suggest that reports at 3 years are likely to underestimate the numbers of children with moderate disability. ${ }^{33}$ In this study there was $89 \%$ concurrence in the assignment of neuromotor status among those children seen at both 2 and 4.5 years; most of the newly diagnosed cases were of a milder nature.

Comparisons of disability rates between populations are difficult because even where the overall assessment is based on strict criteria covering individual aspects of development, it is the interaction between these spheres which influences how the child performs in everyday life. A child who has a moderate hearing loss alone cannot be classed along with a child who has perhaps slightly less severe impairments in vision, hearing, and in intellectual capacity. It is in this context that a subjective element contributes to the grading disability. Nevertheless without an overall measure of functional disability it is impossible to summarise the impact of increasing survival rates on long term outcome.

Saigal et al (1989) showed a decreased rate of disability in 3 year old infants with birth weights between 801 and $1000 \mathrm{~g}$ in a comparison of births between 1977-80 and 1981-4, but no difference in impairment without disability or survival rates. ${ }^{34}$ Few of these extremely low birthweight infants seem to have had multiple impairments. In our study of slightly older children where cognitive assessment was included in the judgment of disability status, $33 \%$ of those less than $1000 \mathrm{~g}$ were moderately or severely disabled and $12 \%$ had mulitple systems affected. 
The only similar study covering a nationwide population born in one year and seen at 4.5-5 years is the Netherlands study covering $94 \%$ of livebirths of children in 1983 who either weighed less than $1500 \mathrm{~g}$ or who were born at less than 32 weeks. ${ }^{35}$ They also achieved a follow up rate of $96 \%$. They report their findings in terms of WHO classification of impairments, disabilities, and handicaps.

It must be remembered that this is a classification system; it does not provide definitions of the level of involvement which constitutes a disability except for levels of hearing and vision loss which are specified. This makes direct comparison of the studies difficult. Furthermore, we have deliberately avoided the term 'handicap' as by definition, that requires 'a value to be attached to an individual's situation and experience when it departs from the norm' ... 'It is regarded as a classification of circumstances in which disabled people are likely to find themselves'. ${ }^{10}$ We did not feel our data allowed us to make such assumptions until the children were of an age when they could contribute their own perceptions of their disability and how it affected them 'relative to their peers'. It seemed appropriate therefore to combine the categories of disability and handicap from the Netherlands study for comparison with our findings (table 6).

A higher proportion of the Scottish children died before the age of assessment but this difference was not statistically significant $\left(\chi^{2}=\right.$ 3.36 , df $1, p>0.05)$. The proportion who were disabled/handicapped in the Dutch study was $28.5 \%$ compared with $17 \cdot 6 \%$ in this study $\left(\chi^{2}=15 \cdot 2, \mathrm{df} 1, \quad \mathrm{p}<0 \cdot 001\right)$. The differences between the studies in the proportion who were normal and impaired was so great that they must be due to definitional differences.

Our 'normal' children were defined as having an IQ of 85 or over, no neurological signs, visual acuity of $6 / 12$ or better, and no detectable hearing loss on clinical grounds. Some were perhaps clumsy. Given these caveats, a comparison of the findings for those below $1500 \mathrm{~g}$ is shown in table 6.

One possible explanation is that in the Dutch study a screening test (the Denver developmental screening test) was used whereas in the Scottish study, a diagnostic psychometric test was administered. The former by definition will have false positives.

In addition, they had access to audiometry on all the children which may have identified more cases with hearing loss which did not interfere with functional performance. Comparisons on

Table 6 Comparison of findings on children with birth weights less than $1500 \mathrm{~g}$ with those of 1983 Netherlands study ${ }^{I 7}$

\begin{tabular}{lll}
\hline & Netherlands study & Scottish study \\
\hline No of livebirths & 1097 & 603 \\
Dead & 330 & 197 \\
No (\%) eligible for assessment & $767(69 \cdot 9)$ & $373(61 \cdot 8)$ \\
No (\%) assessed & $736(96 \cdot 0)$ & $358(96 \cdot 0)$ \\
'Normal' & $156(21 \cdot 2)$ & $187(52 \cdot 2)$ \\
Impaired & $370(50 \cdot 3)$ & $105(29 \cdot 3)$ \\
'Disabled' or 'handicapped' & $210(28 \cdot 5)$ & $66(18 \cdot 4)$ \\
\hline${ }^{\circ} \chi^{2}=13 \cdot 0$ dfl p<0.001. &
\end{tabular}

${ }^{7} \chi^{2}=13.0$ dfl $p<0.001$. neuromotor function cannot be made since the motor developmental assessment used is not specified, nor the cut off point used to define impairment. The neurological assessment carried out was, however, designed to be very similar (P Verloove-Vanhorick, personal communication).

Nevertheless, the definition of disability is the same in both studies. It is unlikely that children who were considered clumsy by the TOMI would have been considered disabled in the Dutch population.

A more optimistic perspective from our study is that $62 \%$ of liveborn infants weighing less than $1500 \mathrm{~g}$ in 1984 survived to 4.5 years and that $60 \%$ of these were considered normal on the basis of the assessments carried out. Among those with birth weight between 1500 and 1749 g, $89 \%$ survived and $64 \%$ of the survivors were judged to be normal. Although survival rate is much higher in the heavier weight group, the proportion thought to be normal is not dissimilar.

Together with children with minor impairments, like squints, refractive errors or IQs between $70-84,82 \%$ of the survivors who had weighed less than $1500 \mathrm{~g}$ and $85 \%$ of the heavier group were expecting to attend normal schools; in addition, some of the moderately disabled children will be integrated into normal schools.

These findings and those in the accompanying paper suggest that a substantial proportion of these children will continue to require support from the health and educational services well into the future.

We are grateful to the chief administrative medical officers in each health board for funding the time and travel of the community child health doctors participating in the study; to Toni Lynch for administration of the field work, and to Gaye Bell for patiently coping with the redrafting process. We acknowledge with gratitude the helpful comments of colleagues within the unit.

Most of all we would like to thank the children and their parents who gave up their time to the study.

The personnel involved in the planning, administration, and analysis of the project, Lesley Mutch, Anna McGee, Toni Lynch, and Gaye Bell, were supported by the Medical Research Council.

1 Chalmers I, Mutch L. Are current trends in perinatal practice associated with an increase or a decrease in handicapping associated with an increase or a de

2 Stewart AL, Reynolds EOR, Lipscomb AP. Outcome for infants of very low birthweight: survey of world literature. Lancet 1981;i:1038-41.

3 Kiely J, Paneth W, Stanley F. Monitoring the morbidity outcomes of perinatal health services. In: Stanley F, Alberman $\mathrm{E}$, eds. The epidemiology of the cerebral palsies. Clinics in developmental medicine No 87. Oxford: Spastics International Medical Publications, 1984:150-71.

4 McIlwaine G, Mutch L, Pritchard C, Fletcher DV. The Scottish low birthweight study: the pregnancies, neonatal progress and outcome at two years. Edinburgh: Report to Scottish Home and Health Department, 1989.

5 Tanner JM, Whitehouse RH, Takaishi M. Standards from birth to maturity for height, weight, height velocity, and weight velocity: British children, 1965. Arch Dis Child 1966;41:454-71.

6 Tanner JM, Whitehouse RH, Takaishi M. Standards from birth to maturity for height, weight, height velocity, and weight velocity: British children, 1965. Arch Dis Child 1966;41:613-35.

7 Rolland-Cachera MF, Cole TJ, Sempe M, Tichet J, Rossignol C, Charraud A. Body mass index variations: centiles from birth to 87 years. Eur $\mathcal{f}$ Clin Nutr 1991;45: centiles

8 Amiel-Tison C, Stewart A. Follow up studies during the first five years of life: a pervasive assessment of neurological five years of life: a pervasive assessment of
function. Arch Dis Child 1989;64:496-502.

9 Henderson SE. Henderson revision of the Stott-MoyesHenderson test of motor impairment. Guelph, Ontario: Henderson test of motor impairmen

10 World Health Organisation. International classification of impairments, disabilities and handicaps. Geneva: WHO,
1980 . 
11 Cole S. Scottish maternity and neonatal records. In: Chalmers I, Mcllwaine G, eds. Perinatal audit and surveillance. London: Royal College of Ostetricians and Gynaecologists, 1980:39-51.

12 Michelsson K, Noronen $M$. Neurological, psychological and articulatory impairment in five-year-old children with a birthweight of $2000 \mathrm{~g}$ or less. Eur $\mathcal{F}$ Pediatr 1983;141: 96-100.

13 Klein NK, Hack M, Breslan H. Children who were very low birthweight: development and academic achievement at 9 years of age. 7 Dev Behav Pediatr 1989;10:32-7.

14 Kitchen WH, Ford G, Rickards A, Lissenden J, Ryan MM. Children of birthweight $<1000 \mathrm{~g}$ : changing outcome between ages 2 and 5 years. F Pediatr 1987;110:283-8.

15 Lloyd BW, Wheldall K, Perks D. Controlled study of intelligence and school performance of very low birthweight children from a defined geographical area. Dev Med Child Neurol 1988;30:36-42.

16 Saigal S, Szatmari P, Rosenbaum P, Campbell D, King S. Intellectual and functional status at school entry of children who weighed $1000 \mathrm{~g}$ or less at birth: a regional perspective of births in the 1980s. F Pediatr 1990;116:409-16.

17 Abel Smith AE, Knight-Jones EB. The abilities of very lowbirthweight children and their classroom controls. Dev Med Child Neurol 1990;32:590-601.

18 Powell TG, Pharoah POD, Cooke RWI. Survival and morbidity in a geographically defined population of low morbidity in a geographically defined pop

19 Drillien CM. A longitudinal study of the growth and development of prematurely and maturely born children. Arch Dis ment of prematurely and

20 Kimble KJ, Ariagno RL. Stevenson DK, Sunshine P. Growth to age three years among very low birthweight
survivors of modern neonatal intensive care. $\mathcal{f}$ Pediatr survivors of moder

21 Ross G, Lipper EG, Auld PAM. Physical growth and developmental outcome in very low birthweight premature infants at 3 years of age. $\mathcal{F}$ Pediatr 1985;107:284-6.

22 Dunn HG, ed. Sequelae of low birthweight. The Vancouver study. Clinics in developmental medicine 95/96. Oxford: Blackwell Scientific Publications and MacKeith Press, 1986.
23 Kitchen WH, Ford GW, Doyle LW. Growth and very low birthweight. Arch Dis Child 1989;64:379-82.

24 Forslund $M$, Bjerre I. Follow up of preterm children. II Growth and development at four years of age. Early Hum Dev 1990;24:107-18.

25 Casey PH, Kraemer HC, Bernbaum J, et al. Growth patterns of low birthweight preterm infants: a longitudinal analysis of a large varied sample. $\mathcal{F}$ Pediatr 1990;117:298-307.

26 Mutch L, Leyland A. Growth and nutrition in children with cerebral palsy Lancet 1990;ii:569-70.

27 Kitchen WH, Ryan MM, Rickards A, et al. Changing outcome over 13 years of very low birthweight infants. outcome over 13 years of very
Semin Perinatol 1982;6:373-89.

28 Richards AL, Ford GW, Kitchen WH, Doyle LW, Lissenden JV, Keith CG. Extremely low birthweight infants: neurological psychological growth and health status beyond 5 years of age. Med F A ust 1987;147:476-81.

29 Kitchen WH, Ford G, Orgill A, et al. Outcome in infants with birthweights $500-999 \mathrm{~g}$ : a regional study of 1979 and 1980 births. I Pediatr 1984;104:921-7.

30 Mutch LMM, Johnson MA, Morley R. Follow up studies: design, organisation and analysis. Arch Dis Child 1989;64: $1394-402$.

31 Johnson MA, Cox M, McKim E. Outcome of infants of very low birthweight: a geographically based study. Can Med Assoc $\mathcal{F}$ 1987; 136:1157-65.

32 Stewart AL, Costello AM, Hamilton PA, et al. Relationship between neurodevelopmental status of very preterm infants at one and four years. Dev Med Child Neurol 1989;31: at one

33 Stanley FJ. Using cerebral palsy data in the evaluation of neonatal intensive care: a warning. Dev Med Child Neurol 1982;24:93-4.

34 Saigal S, Rosenbaum P, Hattersley B, Milner R. Decreased disability rate among 3 year old survivors weighing 501 to $1000 \mathrm{~g}$ at birth and born to residents of a geographically defined region from 1981 compared with 1977 to 1980 . $\mathcal{f}$ Pediatr 1989;114:839-46.

35 Veen S, Ens Dokkum MH, Schreuder AM, Verloove Vanholick SP, Brand R, Ruys JH. Impairments, disabilities and handicaps of very preterm and very low birthweight infants at 5 year of age. Lancet 1991;338:33-6. 